\title{
Method of Instrumental Monitiring During Operation of Buildings and Structures with Account for Vulnerability Factor
}

\author{
P. E. Hrihorovskiy \\ https://doi.org/10.31174/SEND-NT2018-157VI17-03 \\ State Enterprise «Research Institute of Building Production named of V.S.Balitsky», Kyiv, Ukraine \\ Paper received 23.01.18; Accepted for publication 30.01.18.
}

\begin{abstract}
The article deals with methodological issues concerning the developing the structure and content of instrumental monitoring during operation of buildings and structures. The results confirming the dependence of the life cycle duration of construction objects on the timely taking into account the threats of damage to structural elements, were obtained. The research on prediction of the technical state under the influence of factors with different properties was fulfilled. The factor of the building's vulnerability as a property of losing operational integrity as a result of damage under the influence of a certain type of negative factors, was introduced and evaluated.
\end{abstract}

Keywords: life cycle of buildings, instrumental monitoring, methods, vulnerability.

Introduction. During operation, buildings and structures are subjected to numerous natural and man-made actions, which must be taken into account when selecting materials, designing structures and assembly units. However, in practice, the characteristics of building materials and structures may not meet the requirements of the design documentation and as a result the combined effect of many factors will lead to premature wear of the building. The life cycle of a building depends not only on the quality of construction materials and the quality of construction operations but also on the maintenance operation, timely and accurate taking into account the damage to buildings and prediction of the dynamics of their technical condition, which is impossible without measuring operations to obtain data for its safe use.

Review of the articles on the subject. Problems of instrumental monitoring the state of the objects being used become more and more complicated over time. This is due to increasing complexity of buildings and structures, constant dynamics in developing the established standards for monitoring [1, 2] and a variety of methods of monitoring [3]. Modern construction science is characterized by existence of comprehensive directions for this problem the main parts of which are the normative and scientific works of $\mathrm{V}$. Balitskii and his co-authors: [3] V. Kazachek [4], N. Grechko [6], I. Shumakov [7]. However, normative works dominate in this process. In addition, among the authors of scientific research works there is no consensus on assessing the impact of factors of different nature for formation of an instrumental monitoring system for buildings, there is no methodology of monitoring observations, the factors that influence on the technical state of the object during its life cycle are not classified, and most importantly - an index of vulnerability of buildings, structures and territories are not taken into account.

Purpose. Creation of instrumental monitoring method taking into account vulnerability of buildings and structures.

Research results. The duration of the life cycle of buildings depends to a large extent on the timely taking into account the damage to the building and prediction of deterioration of their technical condition under the influence of external (natural, man-made) and internal (structural, operational) threats. Currently, on the territory of Ukraine there are more than 20 types of geological processes, including natural, man-triggered and natural and purely man-made ones, which have a significant impact on emergencies.

The assessment of damage risks for construction projects is based on engineering research in construction carried out when taking the advanced engineering, technical and other measures to reduce negative effects caused by geological processes and to prevent natural disasters. When assessing risks, all possible cases of activation of existing and emerg- ing impact factors, the characteristics of the source of the threat (distance from its source to the building, parameters that characterize the power of the source of the threat), the technical condition of existing buildings, the distance to the building being built in the compacted area, etc., should be considered.

In order to assess the risk of damage, in addition to identifying the possible causes of this process, it is proposed to assess vulnerability of the building and the area around it. It is suggested to consider the tendency of the building to lose its operational integrity as a result of damage due to certain factors as vulnerability. The degree of vulnerability of a building depends on the characteristics of the building itself, the characteristics and the state of the soil base and surrounding area. An attempt to quantify the extent of the factors leads to the need to characterize the emerging dangerous situation.

The «ideal» variant to assess vulnerability $k_{y}$ is a hypothetical process characterized by a lack of symptoms that identify an unsafe process in the combined effect of all factors. In this case $\left\{\min k_{y}\right\}=0$. Taking into account the principles of valuation of characteristics, the maximum danger for the territory can be $\left\{\min k_{y}\right\}=1$, so it is possible to write: $0 \leq k_{y} \leq 1$.

Characteristics of the building and the territory reflecting the vulnerability are represented in Table. 1 . The table specifies the parameters that characterize the vulnerability, their conditional codes $y_{i}$, and the conditional subcodes of the parameters $y_{i 1}, y_{i 2}, y_{i 3}$ that have little, medium and maximum effect respectively. If the parameters are determined numerically, the vulnerability can be defined from the expression that characterizes the dependence of vulnerability on the value of the parameter under the condition that this dependence is linear.

Table 1. Parameters of a building that determine its vulnerability

\begin{tabular}{|c|c|c|}
\hline $\begin{array}{c}\text { Group } \\
\text { code }\end{array}$ & $\begin{array}{c}\text { Subgroup } \\
\text { code }\end{array}$ & \multicolumn{1}{|c|}{ Name of the parameter and its value } \\
\hline \multirow{4}{*}{$y_{i}$} & \multicolumn{2}{|c|}{ Parameter $i$} \\
\cline { 2 - 3 } & $y_{i l}$ & $\begin{array}{l}\text { Value of parameter } i \text { that has a minimum } \\
\text { impact on vulnerability }\end{array}$ \\
\cline { 2 - 3 } & $y_{i 2}$ & Medium value of parameter $i$ \\
\cline { 2 - 3 } & $y_{i 3}$ & $\begin{array}{l}\text { Value of parameter } i \text { that has a maximum } \\
\text { impact on vulnerability }\end{array}$ \\
\hline
\end{tabular}

Given that at this stage the databases concerning the impact of various factors on the vulnerability are not sufficiently developed, the degree of impact can be assessed by method of expert assessment by specialists involved in design and operation of buildings. The typical result of the expert assessment is shown in Fig. 1. In future, it is suggested not to use all parameters but only those that have the largest value. 
To determine the dependence of vulnerability of a building to a specific parameter the given values are used. The given value $i$ is the maximum vulnerability factor to a particular parameter $y_{i 3}$. The given maximum vulnerability factor $y_{i 3}$ to the parameter is defined as a ratio of the value of the rank $r_{i}$ obtained as a result of the expert assessment to the sum of all the ranks to be used, i.e.:

$$
y_{i 3}=r_{j} / \sum_{i=1}^{n} r_{i},(1)
$$

where $j$ is number of vulnerability value; $i$ is a consecutive number of vulnerability value to be used; $n$ is quantity of values to be used.

A degree of lower vulnerability is determined as $y_{i 2}=0,67 \cdot y_{i 3}$ and $y_{i 1}=0,33 \cdot y_{i 3}$ if the parameters are defined by some statement (Fig. 2).

If values of the parameters are numeric, the vulnerability factor to a particular parameter can be determined by expressions (2) and (3) and the diagrams of these expressions are presented in Fig. 3.

$$
\begin{gathered}
\left(x \cdot \frac{0,33}{x_{i 1}}\right) \cdot y_{i 3}, x<x_{i 1} \\
y_{i}=\left(0,33+\left(x-x_{i 1}\right) \cdot \frac{0,67-0,33}{x_{i 2}-x_{i 1}}\right) \cdot y_{i 3}, x \geq x_{i 1},(2) \\
y_{i 3}, y_{i} \geq y_{i 3} . \\
\left(1-x \cdot \frac{0,33}{x_{i 1}}\right) \cdot y_{i 3}, x<x_{i 1}, \\
y_{i}=\left(1-\left(x-x_{i 1}\right) \cdot \frac{1,0-0,33}{x_{i 2}-x_{i 1}}\right) \cdot y_{i 3}, x \geq x_{i 1},(3) \\
y_{i}<0,
\end{gathered}
$$

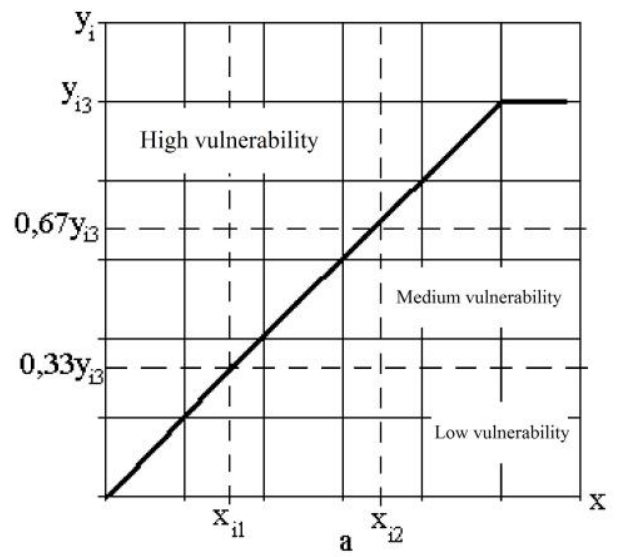

Fig. 3. Vulnerability function pattern: $\mathrm{a}$ - for expression (2); $\mathrm{b}$ - for expression (3)

For assessment the vulnerability factor to all factors $k_{i}$ will be used as maximum probability of influence of a particular factor on the damage to the building, which is determined by the sum of vulnerability factors of a particular building to individual parameters of the factor:

$$
k_{y}=\sum_{i=1}^{n} y_{i},(4)
$$

where $y_{i}$ is a given numerical value of the impact parameter $i ; n$ is quantity of impact parameters for the object.

Damage at possible risks depends not only on the vulnerability of the buildings but also on the characteristics of the source of the threat, the technical condition of existing buildings, the distance to the building being built in the compacted area. Characteristics of the source of the threat may include remoteness of the source from the building or the parameter indicating the power of the source of the threat. These factors can be assessed in each particular case on the grounds of the literature sources or by the method of expert assessment as coefficient of threat significance $k_{3}$ to the resulting vulnerability factor. Characteristics of the sources of the threats are reduced to a separate table (Table 2). In order to take into account the degree of responsibility of the building, the coefficient of significance $k_{c}$ is taken, which indicates the degree where $y_{i}$ is vulnerability to parameter $i ; x$ is value of the parameter; $y_{i 3}$ is value of the maximum given vulnerability factor to the parameter $i ; x_{i 1}, x_{i 2}$ are parameter values that illustrate low, medium and high vulnerability.

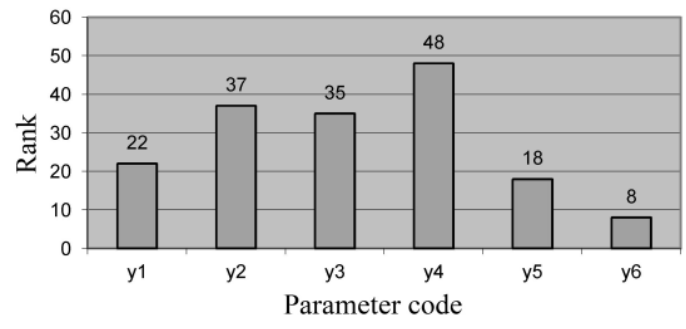

Fig.1. Example of expert assessment results

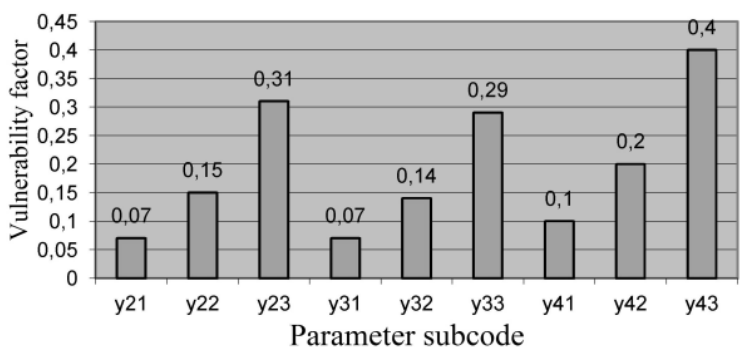

\begin{tabular}{|c|c|c|c|}
\hline \multirow{3}{*}{$\begin{array}{l}\text { Parameter of } \\
\text { treat sources }\end{array}$} & \multicolumn{3}{|c|}{ Degree of threat } \\
\hline & high & medium & low \\
\hline & \multicolumn{3}{|c|}{$\begin{array}{l}\text { Parameter value, (coefficient of signifi- } \\
\text { cance), } k_{3 H}\end{array}$} \\
\hline Parameter $i$ & $\left(k_{3 i}=1\right.$ & $k_{3 i}=1,(1$ & $i=0,9)$ \\
\hline
\end{tabular}

Fig. 2. Example of determining the vulnerability factor to the parameter as a result of expert assessment

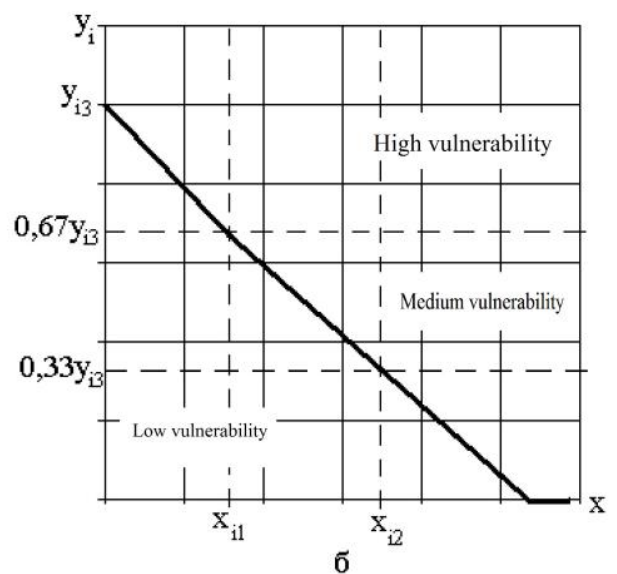

of importance according to Table 3. To characterize the technical condition of the building, the coefficient of significance $k_{m}$ is introduced in accordance with Table 4.

Table 2. Characteristics of treat sources

In this case the building`s vulnerability factor $k_{y \sigma}$ to a particular risk factor can be represented by such expression:

$$
k_{\text {уб }}=k_{\mathrm{s}} \cdot k_{\mathrm{c}} \cdot k_{m} \cdot k_{y},(5)
$$

where $k_{3}$ is the coefficient of significance of the threat source, power of the threat, etc.; $k_{\mathrm{c}}$ is the coefficient of significance indicating a degree of responsibility of a building; $k_{m}$ is the coefficient of significance of technical condition of a building; $k_{y}$ is vulnerability factor from (4).

The values of the coefficients of significance are determined on the grounds of literature sources, experimental 
investigations or the expert survey method. The most optimal values are given in Tables $2-4$.

Table 3. Coefficient of significance of responsibility degree of building

\begin{tabular}{|c|c|c|}
\hline Symbol & Value & Characteristic \\
\hline \multirow{3}{*}{$k_{c}$} & 0,9 & Responsibility degree CC1 \\
\cline { 2 - 3 } & 1,0 & Responsibility degree CC2 \\
\cline { 2 - 3 } & 1,1 & Responsibility degree CC3 \\
\hline
\end{tabular}

Table 4. Coefficient of significance of technical condition of building

\begin{tabular}{|c|c|c|}
\hline Symbol & Value & Condition characteristic \\
\hline \multirow{2}{*}{$k_{m}$} & 1,0 & normal \\
\cline { 2 - 3 } & 1,2 & satisfactory \\
\hline & - & $\begin{array}{r}\text { unserviceable }- \text { it is necessary to carry out a struc- } \\
\text { tural survey and to take a decision about total } \\
\text { building renovation }\end{array}$ \\
\hline- & - & $\begin{array}{c}\text { unfit building - it is necessary to carry out a struc- } \\
\text { tural survey of the building and to take a decision } \\
\text { about its refurbishment or dismantlement }\end{array}$ \\
\hline
\end{tabular}

If there are several parameters of threats, they are considered separately and the largest value is taken to assess the threat $k_{3}=k_{3}^{\max }$. If there are several sources of threats, the decisions about structural survey are taken separately for each source, but if the possible means of monitoring are the same, they are combined to monitor the influence of all sources.

A vulnerability grade (low, medium, high) to a specific risk factor is defined for taking a decision concerning the expediency of structural survey and its definition:

- low vulnerability:

$$
k_{\text {y }} \leq 0,33 \cdot k_{y \max }=0,33 \text {, (6) }
$$

where $k_{y \text { max }}$ is highest possible value of the vulnerability factor, $k_{y \max }=1,0$ without taking into account the coefficients of risk factors;
- medium vulnerability:

$$
0,33>k_{\mathrm{y} \sigma}>0,67,(7)
$$

- high vulnerability:

$$
k_{\text {уб }}>0,67 \text { (8) }
$$

The vulnerability grade of the building can have values larger than 1.0 if to take into account the coefficient of significance of threat, the degree of responsibility, etc.

The decision about necessity of the structural survey, its definition and frequency are taken based on the results of the vulnerability factor determination:

- at low vulnerability factor of the building, the monitoring level should be normal, i.e. taking into account low probability of damage, it is possible not to carry out instrumental monitoring but to limit the survey by visual observation during the periodical planned inspections;

- in case of medium building vulnerability, the monitoring level should be increased, i.e., taking into account the average probability of damage, besides the visual observation during the periodical planned inspections, additional periodical instrumental examinations are necessary in order to investigate the possible relationship between the values of the parameters and the dynamics of the detected damages;

- in case of high vulnerability of the building, the monitoring level should be special, that is, taking into account high probability of damage, the object must be equipped with an additional automated monitoring system to prevent emergencies. The system's elements and the controlled parameters are determined individually taking into account the analysis of possible threats and damages.

Conclusions. Based on the results of the above method it is possible to predict the further development of processes. The frequency of control is determined by the maximum possible rate of change of the monitored parameter taking into account the ratio of the cost of this work to possible losses from delayed detection of damage.

[1] Analitichnyi ogliad stanu tehnogennoi ta prirodnoi bezpeki v Ukraini za 2015 rik [Electronnyi resurs] / Derzhavna sluzhba Ukrainy z nadzvychainykh situatsii. - Rezhim dostupu: http://www.dsns.gov.ua/ua/Analitichniy-oglyad-stanutehnogennoyi-ta-prirodnoyi-bezpeki-v--Ukrayini-za-2015rik.html (20.01.17). - Nazva z ekranu.

[2] Normatyvni dokumenty z pytan obstezhen, pasportyzatsii, bespechnoi ta nadiinoi ekspluatatsii vyrobnychykh budivel $\mathrm{i}$ sporud. - K.: NDIBV, 2003. - $144 \mathrm{~s}$.

[3] Balytskyi V. Nastanova shchodo obstezhennia budivel i sporud dlia vyznachennia ta otsinky ikh technichnogo stanu : DSTU-N B V.1.2- 18:2016. - [Chynnyi z 2017-04-01] / V. Balytskyi, O. Galinskyi, O. Garmash, P. Grygorovskyi ta in. - K. : DP «UkrNDNTs», 2017. - 47 s. - (Natsionalnyi standart Ukrainy).

[4] Kazachek V.G. Problemy normirovaniia srokov sluzhby zdanii i sooruzhenii / V.G. Kazachek/ Vestnik Polotskogo gosudarstvennogo universiteta. - Minsk : Komitet po tekhnicheskomu normirovaniiu i standartizatsii v oblasti arkhitektury i stroitelstva. Seriia F. 2010. - S. 56-71.

\section{ENCES}

[5] Grygorovskyi P.E. Osoblyvosti rozrakhunku trudovytrat na provedennia geodezychnykh robit u budivnytstvi : [tekst] / P.E. Grygorovskyi, N.P. Chukanova // Suchasni dosiagnennia geodezychnoi nauky ta vyrobnytstva : zb. nauk. pr. Zakhidnogo geodezychnogo tovarystva UTGK. - Lviv : Vyd-vo Lvivskoi politekhniky, 2014. - Vyp. 1(27). - S.148-151.

[6] Grechko N.V. Optimizatsionnye zadachi prognozirovaniia parametrov protsessa ustroistva vysokoprochnykh betonnykh polov/ N.V. Grechko, I.V.Shumakov, V.N.Sekretnaia, D.V. Rakyvnenko //Naukovyi visnyk budivnytstva. , 2014.- № 1. -S. 55-56. Rezhim dostupu : : http://nbuv.gov.ua/UJRN/Nvb_2014_1_14

[7] Shumakov I.V. Vysokoprochnye betonnye poly : tekhnologii, kachestvo, dolgovechnost : monografiia [Elektronnyi resurs] / I.V.Shumakov, V.N.Sekretnaia //Kharkov : Miskdruk, 2016.-220 s. $\quad-\quad$ Rezhim dostupu http://mirknig.su/knigi/stroitelstvo_i_remont/130079vysokoprochnye-betonnye-poly-tehnologii-kachestvodolgovechnost.html

\section{Методика инструментальных наблюдений при эксплуатации зданий и сооружений с учетом показателя уязвимости П. Е. Григоровский}

Аннотация. В статье раскрыты методологические вопросы по формированию структуры и содержания инструментальных наблюдений при эксплуатации зданий и сооружений. Получены результаты, которые свидетельствуют о зависимости продолжительности жизненного цикла строительных объектов от своевременного учета угроз повреждения конструктивных элементов. Выполнены исследования по прогнозированию технического состояния при влиянии факторов с разными свойствами. Введен и оценен показатель уязвимости здания как свойство терять эксплуатационную пригодность в результате возникновения повреждения под влиянием определенного типа негативных факторов.

Ключевые слова: жизненный цикл зданий, инструментальные наблюдения, методы, уязвимость. 